\title{
The effect of transition cow housing on lying and feeding behavior in Holstein dairy cows
}

\author{
M. R. Campler, ${ }^{*} †$ L. Munksgaard, and M. B. Jensen \\ Department of Animal Science, Aarhus University, PO Box 50, 8830 Tjele, Denmark
}

\begin{abstract}
The present study investigated the effect of straw yard housing during the dry period and $2 \mathrm{~d}$ of additional maternity pen housing postcalving on lying and feeding behavior and calving difficulty in Holstein dairy cows. In this study, 122 multiparous cows were moved to either a straw yard or into freestall housing $4 \mathrm{wk}$ before their expected calving date. Cows that had been housed in straw yards stayed in the maternity pen for an additional $2 \mathrm{~d}$ after their calving day, but cows that had been housed in freestalls were moved to the general lactation group the morning after calving. Lying time, lying bouts, feeding time, number of feeder visits, feed intake, feeding rate, and assisted calvings were recorded. Observations were divided into 2 periods: precalving (the 4-wk dry period before calving) and postcalving (the day of calving and the $2 \mathrm{~d}$ after). During the precalving period, cows housed in straw yards showed a higher number of lying bouts but no difference in lying time compared with cows housed in freestalls. Cows that were housed longer in the straw-bedded maternity pen postcalving spent more time lying during the $2 \mathrm{~d}$ postcalving and had a higher number of lying bouts on the day of calving than cows moved to the freestall area on the day postcalving. Additionally, cows that were housed longer in the maternity pen had a slower feeding rate and longer total feeding time during the $2 \mathrm{~d}$ after calving than cows with a shorter stay in the maternity pen. We found no difference in the number of assisted calvings. This study suggests that straw yard housing during the dry period may facilitate the transition between standing and lying. Furthermore, the extended stay in the maternity pen postcalving increased lying time, the number of lying bouts, and
\end{abstract}

Received February 22, 2019.

Accepted April 25, 2019.

*Corresponding author: magnus.campler@uky.edu

$\dagger$ Current address: Department of Animal and Food Sciences, UK Dairy Program, University of Kentucky, 407 W. P. Garrigus Building, Lexington, KY 40546. feeding time, but decreased feeding rate compared with cows that were moved to the general lactation group on the day postcalving. These results suggest potential recovery benefits with an extended stay in a maternity pen postcalving. However, further studies are needed to separate the effects of housing in the dry period and the effects of an extended housing in individual maternity pens.

Key words: dairy cow, behavior, straw yard, transition period

\section{INTRODUCTION}

Dairy cows spend approximately 8 to $16 \mathrm{~h}$ of their daily time budget lying down (e.g., DeVries and von Keyserlingk, 2005; Cook et al., 2007; Gomez and Cook, 2010; Westin et al., 2016), suggesting that the opportunity to lie down comfortably is of great importance (Tucker et al., 2003). Previous studies have reported that lying behavior can have higher priority than other behaviors (Metz, 1985; Munksgaard et al., 2005; Cooper et al., 2007). Housing that restricts lying opportunities or prevents lying behavior has been reported to induce behavioral or physiological stress responses (Munksgaard and Simonsen, 1996; Fisher et al., 2002). Previous studies in lactating dairy cows have shown that they prefer lying down on thick (Tucker et al., 2009) and soft (van Gastelen et al., 2011) bedding. Additionally, Calamari et al. (2009) reported that lactating cows prefer freestalls bedded with stand or straw over freestalls equipped with rubber mats or mattresses without additional bedding substrates. In a study using both dry and lactating cows, Norring et al. (2008) also found that cows housed in a freestall environment preferred stalls bedded with straw or sand compared with freestalls without bedding. Although some studies have investigated lying behavior in dry cows (e.g., Tucker and Weary, 2004; Jensen et al., 2005; Fregonesi et al., 2007), the majority investigating lying behavior and preferences for lying surfaces have been conducted on lactating cows.

An early study by Huzzey et al. (2005) observed behavioral changes in periparturient cows, with increased 
standing times from the day before calving until the day after calving and a higher number of transitions between lying and standing on the day of calving. Jensen (2012) reported similar findings, with an increase in the number of lying bouts on the day of calving and particularly during the last $6 \mathrm{~h}$ before calving, suggesting a need for a non-slippery substrate to facilitate these behavioral changes close to calving. Schirmann et al. (2012) reported similar lying patterns in dry cows compared to lactating cows, suggesting similar needs to lie down during the dry period and the lactation period. Kok et al. (2017) reported shorter lying times in cows with no dry period $(12.6 \mathrm{~h} / \mathrm{d})$ compared with cows with a short dry period $(13.7 \mathrm{~h} / \mathrm{d})$, suggesting that the dry period allows for additional resting behavior. Kaufman et al. (2016) reported higher lying times for pregnant cows in straw-bedded pack systems compared with in freestalls, and Reich et al. (2010) reported that pregnant dairy cows preferred to lie down on dry bedding materials compared with moist or wet bedding. Finally, a study by Campler et al. (2014) found that cows preferred to give birth on sand rather than on rubber mats (both surfaces covered with straw).

Evidence has shown that lying patterns are inversely related to feeding patterns (e.g., Fregonesi et al., 2007; Schirmann et al., 2012) and linked to rumination patterns after feeding in lactating cows (e.g., Adin et al., 2009), but less information is available for dry and periparturient cows. There is a risk of reduced welfare for cows that are unable to adapt their feeding behavior to environmental and biological changes during the transition period (Ingvartsen, 2006). These cows might be unable to fulfill their nutritional requirements and experience a higher risk of negative energy balance, resulting in lower BCS, an increased risk of production diseases (Vickers et al., 2013; Kadivar et al., 2014; van Knegsel et al., 2014; Randall et al., 2015), and reduced milk production postpartum (Drackley, 1999).

The current literature concludes that soft and dry surfaces are important to dairy cows during the lactation period, and particularly during the dry period and until calving. Furthermore, some cows may be at risk of transition diseases due to an abrupt shift in feeding management. However, little is known about the effect of continued straw yard housing on lying and feeding behavior throughout the dry period and the first sensitive days of the periparturient period, when cows are normally moved back to the lactation herd.

The objective of this study was to investigate the effect of straw yard housing during the last 4 wk of the dry period and extended maternity pen housing for $2 \mathrm{~d}$ after the calving day on lying and feeding behavior in Holstein cows, compared with traditional freestall hous- ing and postcalving management. We predicted that (1) cows given straw yard housing precalving would show increased lying time, more transitions between lying and standing, and have fewer calving difficulties than cows housed in a freestall environment; and (2) cows housed in the maternity pen for an additional $2 \mathrm{~d}$ after calving would have fewer feeder visits and reduced feed rate (due to the absence of competition) than cows moved into a freestall environment postcalving.

\section{MATERIALS AND METHODS}

\section{Experimental Animals, Housing, and Management}

The study included 122 Danish Holstein cows (52 primiparous and 70 multiparous; parity $=2.0 \pm 1.0$, mean \pm SD) and was conducted from February 2012 to December 2012 at the Cattle Research Centre, AU-Foulum, Denmark. Only cows that were healthy at the time of enrollment were included in the study. The health status of each cow was recorded by trained and experienced farm personnel according to the farm's standard operating procedure for the management of cow diseases. Any cow that contracted an illness or transition disease except for calving difficulties was removed from the experiment and the associated data were omitted. Cows were dried off 8 wk before their expected calving date and housed in a dry pen with slatted concrete flooring (slats $=15 \mathrm{~cm}$, spacing $=4$ $\mathrm{cm})$ and freestalls $(1.85 \mathrm{~m} \times 1.35 \mathrm{~m}$, length to brisket locator $\times$ width), yielding a total stall length of $2.75 \mathrm{~m}$, including lunge space. Freestalls were bedded with geotextile mattresses $(1.85 \mathrm{~m} \times 1.35 \mathrm{~m}$; Comfy Cushion, Canarm/BSM; Canarm Ltd., Ontario, Canada) and topped with a thin layer of sawdust on a $2 \%$ slope with a $0.15-\mathrm{m}$ curb height. All freestalls were equipped with standard partitions, a neck rail placed $1.25 \mathrm{~m}$ above the mattress, and a tube-shaped brisket locator $(10 \mathrm{~cm}$ high) at $1.85 \mathrm{~m}$ from the curb. The alley width between the rows of freestalls and from the freestalls to feeders was $3.3 \mathrm{~m}$.

Alleys were scraped by automatic cleaning robots (Lely Discovery; Lely Holding, Maassluis, the Netherlands). Pens were equipped with self-filling water troughs and automatic feeders (Insentec; Hokofarm Group B.V., Marknesse, the Netherlands). Fresh feed was provided every morning and topped up 3 times during the day between 0600 and $2100 \mathrm{~h}$.

\section{Experimental Design}

After an initial dry period of $4 \mathrm{wk}$, all cows were moved and allocated to 1 of 2 treatments: continued 
dry pen housing with freestalls (FS) or 1 of 2 deepbedded straw yards (DS) for the last 4 wk before their expected calving date. The DS pens $(13.6 \mathrm{~m} \times 7.0 \mathrm{~m}$; wall height $=2.0 \mathrm{~m})$ had a lying area $(10.0 \mathrm{~m} \times 7.0$ $\mathrm{m})$ with an average straw depth of $0.5 \mathrm{~m}$ and a feeding area $(7.0 \mathrm{~m} \times 3.6 \mathrm{~m})$ with automatic feed bins over slatted concrete flooring (slats $=15 \mathrm{~cm}$, spacing $=4$ $\mathrm{cm})$. Six maternity pens were adjacent to the DS pens (3 maternity pens located on the long side of each DS pen), where cows were moved before calving. The group compositions of the 3 pens ( $1 \mathrm{FS}, 2 \mathrm{DS}$ ) were dynamic as cows entered once weekly, $4 \mathrm{wk}(28 \pm 4 \mathrm{~d})$ before their expected calving date. The FS pen had a stocking density of 0.5 feed bins per cow and 1 freestall per cow, and a maximum group size of 10 cows at any given time; the DS pens had 0.5 feed bins per cow and a maximum of 10 cows per pen, for a minimum lying area of $7.0 \mathrm{~m}^{2}$ per cow. Straw was replenished regularly during normal barn maintenance. Before calving, all cows were fed a standard dry cow TMR to meet or exceed the nutritional needs of dry cows. On behavioral and physical signs of imminent calving, cows were moved by experienced handlers into individual adjacent maternity pens $(4.0 \mathrm{~m} \times 3.1 \mathrm{~m})$ bedded with deep straw. All maternity pens were equipped with self-filling water bowls and automatic feeders identical to the ones used in the FS and DS pens. All calves were removed between 12 and $18 \mathrm{~h}$ after birth. All enrolled cows from both treatments were taken to a milking robot for the first 7 milking sessions (cows were milked twice daily), and all cows had ad libitum access to water from selffilling bowls and were fed ad libitum from automatic feed bins. Cows previously housed in FS were moved to a dynamic lactation group with a target stocking density of 0.5 feed bins per cow and 1 freestall per cow in a group with a maximum of 60 cows, after their second milking event; DS cows were moved after the afternoon milking on $\mathrm{d} 2$ postcalving. After being moved to the lactation pen, all cows were enrolled in a collaborative feeding strategy experiment and assigned to 1 of 3 feeding strategy groups: (1) control, standard TMR diet and an increase in concentrate (pelleted compound) amount by $150 \mathrm{~g} / \mathrm{d}$, from a start of $1 \mathrm{~kg} / \mathrm{d}$ up to $3 \mathrm{~kg} / \mathrm{d}$ in the milking robot; (2) increased concentrate, increase of $300 \mathrm{~g} / \mathrm{d}$ of concentrate $(1 / 2$ pelleted compound and $1 / 2$ rolled barley) up to $5 \mathrm{~kg} / \mathrm{d}$ in the milking robot; (3) increased bypass protein level in the TMR (20.8 $\mathrm{g}$ of $\mathrm{MP} / \mathrm{MJ}$ vs. $15.8 \mathrm{~g}$ of $\mathrm{MP} / \mathrm{MJ}$ in the control treatment). The feeding treatments and the effects of the feeding strategies are reported in an unpublished manuscript (A. L. F. Hellwing, L. Hymøller, T. Larsen, M. R. Weisbjerg, and M. Larsen, Department of Animal Science, Aarhus University, Foulum, Tjele, Denmark). However, to control for variation due to differences in feeding strategy, we included feed type in the statistical model.

\section{Data Collection}

The observation time was divided into 2 periods: precalving (d 30 to d 1 before calving) and postcalving (calving day to $2 \mathrm{~d}$ postcalving). Calving day was defined as the day of calf expulsion, and data were averaged across the calving day, regardless of the time of calf expulsion. Data for d 1 were obtained throughout the full day after the calving day and data during $\mathrm{d} 2$ postcalving were averaged up to the afternoon milking.

\section{Lying Behavior}

We recorded lying behavior [lying time $(\mathrm{h} / \mathrm{d})$ and number of lying bouts (bouts/d)] $24 \mathrm{~h} / \mathrm{d}$ from $30 \mathrm{~d}$ before calving to $2 \mathrm{~d}$ after calving using automated recording devices (IceTag and IceQube; IceRobotics Ltd., Edinburgh, UK; http://www.icerobotics.com). Each cow had one IceTag or one IceQube attached to their right hind leg $2 \mathrm{~d}$ before treatment allocation. We calculated the number of lying bouts from the raw data, based on the number of device-registered transitions between standing and lying that occurred between standing bouts of at least $30 \mathrm{~s}$. If any chafing was discovered because of the device, the device was removed and attached to the left hind leg for the rest of the experimental period. If both legs were chafed, the device was removed to prevent unnecessary discomfort and the cow was excluded from the study.

\section{Feeding Behavior}

We recorded feeding behavior (feeding time, h/d), number of feeder visits (visits/d), feed intake $(\mathrm{kg} / \mathrm{d}$ ), and feeding rate $(\mathrm{kg} / \mathrm{min}) 24 \mathrm{~h} / \mathrm{d}$ from $30 \mathrm{~d}$ before calving to $2 \mathrm{~d}$ after calving using Insentec automated feed bins (Hokofarm). All cows were assigned a feed bin (2 cows per feed bin) using unique radiofrequency ID ear tags to prevent stealing of feed from other bins; however, some cows occasionally circumvented the feeding gate to gain access to additional feed. Any recorded stealing from a non-allocated feed bin was registered post hoc during data analysis.

\section{Calving Difficulties}

The number of stillborn calves and the severity of the calving process (unassisted, easy with help, hard with help, hard with veterinarian assistance, or cesarean) were observed by experienced barn staff. 


\section{Data Editing and Statistical Analysis}

Lying data from 19 cows precalving and 33 cows postcalving were inaccessible because of activity logger recording problems, such as corrupted data files, lost loggers, or recording failure. The final analysis of lying data precalving included 103 animals (primiparous FS, $\mathrm{n}=23$; multiparous $\mathrm{FS}, \mathrm{n}=30$; primiparous $\mathrm{DS}, \mathrm{n}=$ 20; multiparous DS, $\mathrm{n}=30$ ) and postcalving included 89 animals (primiparous FS, $\mathrm{n}=21$; multiparous FS, $\mathrm{n}=26$; primiparous $\mathrm{DS}, \mathrm{n}=16$; multiparous $\mathrm{DS}, \mathrm{n}=$ 26).

Feeding data were edited by removing cows that stole more than $10 \%$ of their daily intake from feed bins other than the one they were designated $(n=5)$. The final analysis for precalving feeding data included 117 animals (primiparous FS, $\mathrm{n}=26$; multiparous FS, $\mathrm{n}=$ 33 ; primiparous DS, $\mathrm{n}=25$; multiparous $\mathrm{DS}, \mathrm{n}=33$ ). For postcalving feeding data, 1 cow had severe calving difficulties and was euthanized immediately after calving, 2 cows did not receive the correct feed, and $1 \mathrm{cow}$ did not eat after calving; these cows were omitted from the analysis. The final analysis for postcalving feeding data included 113 animals (primiparous $\mathrm{FS}, \mathrm{n}=25$; multiparous FS, $\mathrm{n}=32$; primiparous DS, $\mathrm{n}=24$; multiparous DS, $\mathrm{n}=32$ ). Before analysis, feeding behavior outliers were corrected using the method described by Bossen et al. (2009).

Information about calving difficulties was not noted for 6 cows. The final analysis for calving difficulties included 116 animals (primiparous FS, $\mathrm{n}=26$; multiparous $\mathrm{FS}, \mathrm{n}=34$; primiparous $\mathrm{DS}, \mathrm{n}=25$; multiparous DS, $\mathrm{n}=31$ ).

We performed statistical analyses of differences between treatments in lying and feeding behaviors using SAS software (version 9.3; SAS Institute Inc., Cary, $\mathrm{NC}$ ). Although we used a dynamic dry pen system to represent a normal commercial dairy system, the assumption for data analysis was that cows would be treated as independent units. We performed descriptive analyses and verified the data for normality using the PROC UNIVARIATE procedure and probability distribution plots. Data transformations were deemed necessary for lying bouts and feeding rate variables by using the natural logarithm because the data were not normally distributed. Back-transformed means are presented in text and figures for these variables.

We averaged behavioral variables by week for observations precalving, and analyzed mean values for lying time $(\mathrm{h} / \mathrm{d})$, number of lying bouts (frequency/d), feeding time $(\mathrm{h} / \mathrm{d})$, number of feeder visits (visits/d), feeding rate $(\mathrm{kg} / \mathrm{min})$, and feed intake $(\mathrm{kg} / \mathrm{d})$ using repeated-measures ANOVA (PROC MIXED) with treatment (FS, DS), parity $(0,>1$ for older cows), feed type postcalving (control, increased concentrate, or increased bypass protein), and week $(-4,-3,-2$, and -1 before calving day), as well as their interactions, as main effects. Feed type had an effect on feeder visits: cows fed the control diet had a higher number of visits on d 1 postcalving, and cows fed the increased bypass protein diet had fewer visits on d 2 postcalving than cows fed other feed types. An earlier model also factored in the potential effect of DS cows being in different pens, but pen did not influence the response variables, so it was omitted in the final models. We included cow as a random effect and modeled the covariance between repeated observations of the same cows in successive weeks using autoregressive variance. We used a similar PROC MIXED model for the postcalving period, with treatment (FS, DS), parity $(0,>1$ for older cows), and day $(0,1$, and 2$)$, as well as their interactions, as main effects. We included cow as a random effect and modeled the covariance between repeated observations of the same cows in successive days using autoregressive variance. We used the PDIFF statement in SAS to identify significant pairwise differences between estimated LSM using a Bonferroni post hoc correction. All means and errors represented were estimated by the model.

All models were reduced using a backward elimination process, in which nonsignificant interactions were eliminated. To compare calving difficulties per treatment, we used $\chi^{2}$ goodness of fit. Statistical significance was set at $P<0.05$ and tendencies at $0.05<P<0.10$.

\section{RESULTS}

\section{Precalving}

Lying Behavior. The DS cows had more lying bouts than the FS cows $\left(F_{1,100}=16.34, P<0.001\right.$, Figure 1 ), and the mean number of lying bouts increased during the last week precalving, regardless of treatment $(11.3 \pm 1.0,11.2 \pm 1.0,11.1 \pm 1.0$, and $12.9 \pm 1.0$ per day, mean $\pm \mathrm{SE}$, wk $-4,-3,-2$, and -1 precalving, respectively; $\left.F_{3,215}=22.05, P<0.001\right)$ but we observed no effect of parity $\left(F_{1,100}=0.03, P=0.85\right)$.

Treatments had no effect on total daily lying time precalving (14.4 \pm 0.2 vs. $14.3 \pm 0.2 \mathrm{~h} / \mathrm{d}$, DS and FS, respectively, mean $\left.\pm \mathrm{SE} ; F_{1,100}=0.19, P=0.67\right)$. Primiparous cows spent less time lying down overall than multiparous cows $(13.9 \pm 0.2$ vs. $14.8 \pm 0.2 \mathrm{~h} / \mathrm{d}$, mean $\left.\pm \mathrm{SE} ; F_{1,100}=10.73, P<0.01\right)$, but we observed no difference during wk -4 precalving $(14.8 \pm 0.24$ vs. $14.5 \pm 0.29,15.0 \pm 0.21$ vs. $14.3 \pm 0.25,14.9 \pm 0.20$ vs. $14.1 \pm 0.24$, and $14.4 \pm 0.2$ vs. $12.6 \pm 0.24 \mathrm{~h} / \mathrm{d}$, mean $\pm \mathrm{SE}$, multiparous vs. primiparous cows for wk $-4,-3$, -2 , and -1 precalving, respectively; $F_{3,212}=6.13, P<$ 0.001). Total daily lying time decreased during the last 
week precalving $(14.7 \pm 0.19,14.6 \pm 0.17,14.5 \pm 0.6$, and $13.5 \pm 0.16 \mathrm{~h} / \mathrm{d}$, mean $\pm \mathrm{SE}$, wk $-4,-3,-2$, and -1 precalving, respectively; $F_{3,212}=22.24, P<0.001$ ).

Feeding Behavior. Overall, treatment had no effect on feeding time $(2.9 \pm 0.1$ vs. $2.8 \pm 0.1 \mathrm{~h} / \mathrm{d}$, mean \pm SE, DS vs. FS, respectively; $F_{1,114}=0.24, P=0.63$ ). Multiparous cows spent more time feeding than primiparous cows $(3.2 \pm 0.1$ vs. $2.5 \pm 0.1 \mathrm{~h} / \mathrm{d}$, mean \pm $\left.\mathrm{SE} ; F_{1,114}=38,96, P<0.001\right)$. Overall, we observed a week effect, in which cows spent less time feeding during the week precalving than in other weeks, regardless of treatment or parity $(2.9 \pm 0.1,2.9 \pm 0.1,3.0 \pm 0.1$ and $2.7 \pm 0.1 \mathrm{~h} / \mathrm{d}$, mean $\pm \mathrm{SE}$, wk $-4,-3,-2$, and -1 precalving, respectively; $F_{3,322}=25.62, P<0.001$ ).

We found no treatment effect on feed intake $(32.2$ \pm 0.6 vs. $32.0 \pm 0.6 \mathrm{~kg} / \mathrm{d}$, mean $\pm \mathrm{SE}$, FS vs. DS, respectively; $F_{1,114}=0.13, P=0.72$ ) but feed intake was reduced during the week before calving, regardless of treatment or parity $(33.0 \pm 0.5,33.2 \pm 0.4,32.9 \pm$ 0.4 , and $29.3 \pm 0.4 \mathrm{~kg} / \mathrm{d}$, mean $\pm \mathrm{SE}$, wk $-4,-3,-2$, and -1 precalving, respectively; $F_{3,319}=74.09, P<$ 0.001). Multiparous cows had greater feed intake than primiparous cow $(38.1 \pm 0.5$ vs. $26.0 \pm 0.6 \mathrm{~kg} / \mathrm{d}$, mean $\left.\pm \mathrm{SE} ; F_{1,114}=227.12, P<0.001\right)$.

We found no treatment effect on feeding rate $(0.19$ \pm 1.0 vs. $0.19 \pm 1.0 \mathrm{~kg} / \mathrm{min}$, mean $\pm \mathrm{SE} ; F_{1,114}=0.05$, $P=0.83)$. Multiparous cows had a higher feeding rate than primiparous cows $(0.20 \pm 1.0$ vs. $0.18 \pm 1.0 \mathrm{~kg} /$ min, mean $\left.\pm \mathrm{SE} ; F_{1,114}=11.70, P<0.001\right)$. Overall, feed rate decreased weekly throughout the 4 weeks precalving $(5.28 \pm 0.02,5.25 \pm 0.02,5.23 \pm 0.02$, and 5.20 $\pm 0.02 \mathrm{~kg} / \mathrm{min}$, mean $\pm \mathrm{SE}$, wk $-4,-3,-2$, and -1 precalving, respectively; $F_{3,322}=7.54, P<0.001$ ).

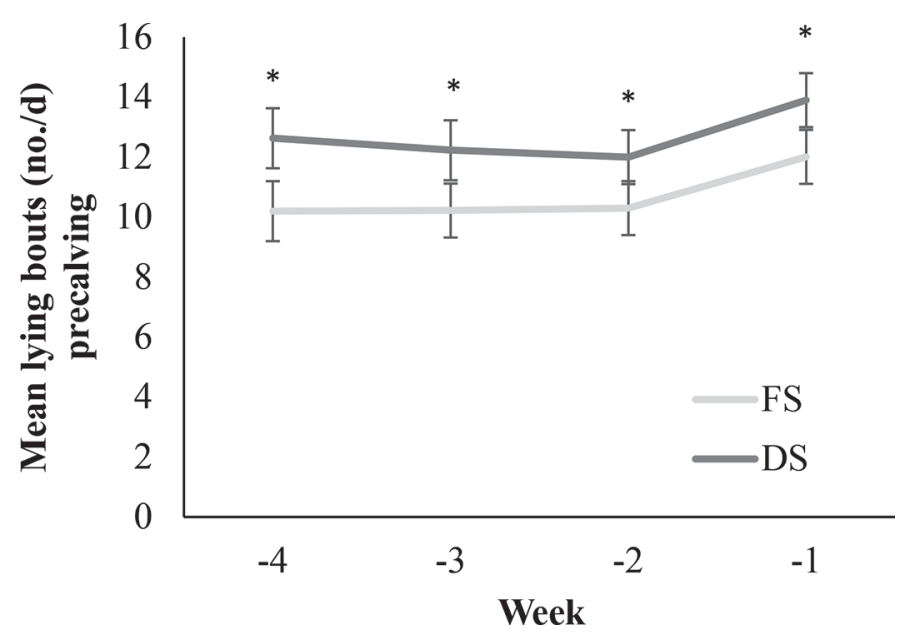

Figure 1. Mean \pm SE lying bouts (no./d) precalving for cows in freestalls $(\mathrm{FS}, \mathrm{n}=53)$ and straw yards $(\mathrm{DS}, \mathrm{n}=50)$ per week precalving. Back-transformed values presented. ${ }^{*}=P<0.05$, significant difference between treatments for week.

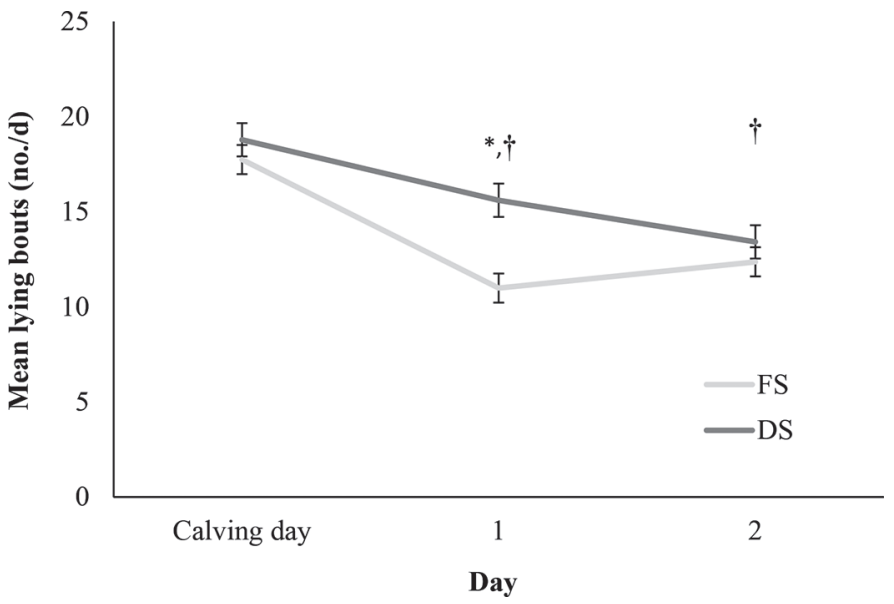

Figure 2. Mean \pm SE lying bouts (no./d) postcalving for cows in freestalls $(\mathrm{FS}, \mathrm{n}=47)$ and straw yards (DS, $\mathrm{n}=42) . \dagger=$ change in housing: DS cows remain in maternity pen; FS are moved to lactation pen. ${ }^{*}=P<0.05$, significant difference between treatments for day.

Cows housed on DS showed a higher number of feeder visits than FS cows $(46.3 \pm 1.0$ vs. $40.4 \pm 1.0$ visits/d, mean $\left.\pm \mathrm{SE} ; F_{1.114}=6.09, P=0.02\right)$. The number of feeder visits was reduced during the week before calving, regardless of treatment or parity $(45.2 \pm 1.0,45.2$ $\pm 1.0,43.3 \pm 1.0$, and $39.6 \pm 1.0 \mathrm{~kg} / \mathrm{d}$, mean $\pm \mathrm{SE}$, wk $-4,-3,-2$, and -1 precalving, respectively; $F_{3322}$ $=10.81, P<0.001)$. We observed no effect of parity on the number of feeder visits $(42.7 \pm 1.0$ vs. $43.8 \pm$ 1.0 visits/d, mean $\pm \mathrm{SE}$, primiparous vs. multiparous, respectively; $\left.F_{1,114}=0.19, P=0.67\right)$.

\section{Postcalving}

Lying Behavior. Overall, DS cows had a higher number of lying bouts than FS cows in the postcalving period $\left(15.9 \pm 0.6\right.$ vs. $13.7 \pm 0.5 ; F_{1.85}=7.33, P<$ 0.01 ) but this result was driven by the fact that DS cows had a higher number of lying bouts on the day after calving than FS cows; we observed no difference on the calving day or the second day postcalving $\left(F_{2,163}\right.$ $=5.26, P<0.01$, Figure 2).

Overall, DS cows spent more time lying than FS cows $\left(10.5 \pm 0.3\right.$ vs. $8.8 \pm 0.3 \mathrm{~h} / \mathrm{d}$, mean $\pm \mathrm{SE} ; F_{1,86}=$ 15.48, $P<0.001)$ and DS cows spent more time lying on each postcalving day $\left(F_{2,161}=6.13, P<0.01\right.$, Figure 3 ), but we observed no difference on the calving day. Multiparous cows spent more time lying postcalving than primiparous cows $(10.8 \pm 0.3$ vs. $8.4 \pm 0.3 \mathrm{~h} / \mathrm{d}$, mean $\left.\pm \mathrm{SE} ; F_{1,86}=31.10, P<0.001\right)$.

Feeding Behavior. The DS cows spent more time feeding than FS cows postcalving $(1.6 \pm 0.1$ vs. $1.3 \pm$ $0.1 \mathrm{~h} / \mathrm{d}$, mean $\left.\pm \mathrm{SE} ; F_{1,109}=11.17, P<0.001\right)$ and DS cows spent more time feeding during $\mathrm{d} 1$ and 2 post- 


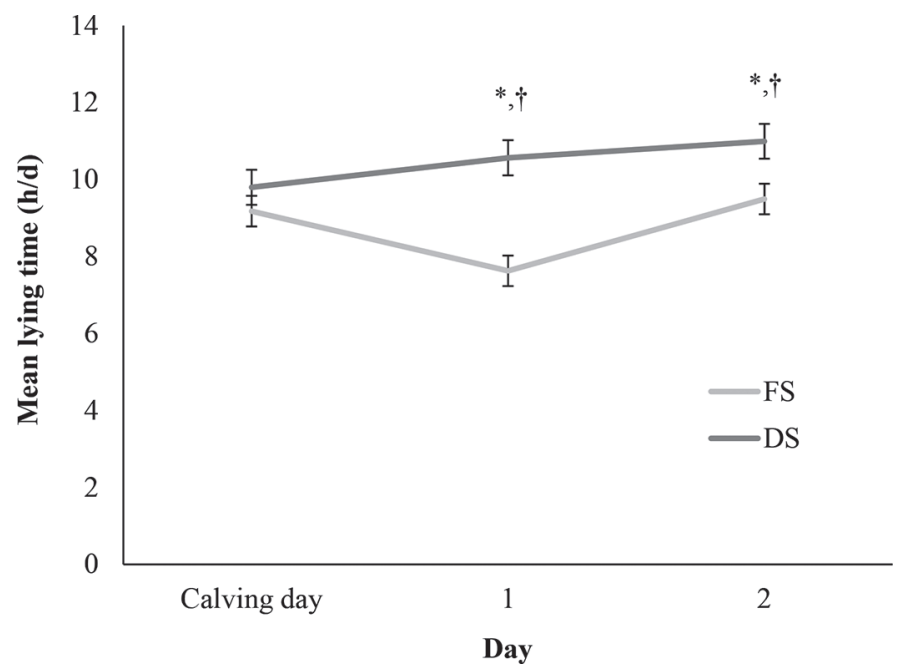

Figure 3. Mean \pm SE lying time (h/d) postcalving for cows in freestalls (FS, $\mathrm{n}=47$ ) and straw yards (DS, $\mathrm{n}=42) . \dagger=$ change in housing: DS cows remain in maternity pen; FS are moved to lactation pen. ${ }^{*}=P<0.05$, significant difference between treatments for day.

calving than FS cows $\left(F_{2,204}=4.77, P<0.01\right.$, Figure 4). Overall, multiparous cows spent more time feeding than primiparous cows postcalving $(1.7 \pm 0.1$ vs. $1.2 \pm$ $0.1 \mathrm{~h} / \mathrm{d}$, mean $\left.\pm \mathrm{SE} ; F_{1,109}=25.92, P<0.001\right)$.

We observed no treatment effect on feed intake postcalving $(22.0 \pm 0.6$ vs. $21.8 \pm 0.6 \mathrm{~kg} / \mathrm{d}$, mean $\pm \mathrm{SE}$; $\left.F_{1,109}=0.01, P=0.91\right)$. However, multiparous cows had a greater feed intake than primiparous cows postcalving $(26.2 \pm 0.7$ vs. $17.4 \pm 0.8 \mathrm{~kg} / \mathrm{d}$, mean $\pm \mathrm{SE}$; $\left.F_{1,109}=63.72, P<0.001\right)$.

The DS cows visited the feeder more frequently than FS cows postcalving $(39.0 \pm 1.5$ vs. $34.5 \pm 1.5$ visits $/ \mathrm{d}$, mean $\left.\pm \mathrm{SE} ; \mathrm{F}_{1,106}=4.86, P=0.03\right)$. Multiparous cows visited the feeder more frequently than primiparous cows $(39.4 \pm 1.4$ vs. $34.2 \pm 1.6$ visits $/ \mathrm{d}$, mean $\pm \mathrm{SE}$; $\left.F_{1,106}=6.06, P=0.02\right)$. We observed a day effect, in which the number of feeder visits decreased on $\mathrm{d}$ 2 postcalving compared with $\mathrm{d} 1$ postcalving and the calving day $(39.3 \pm 1.5,37.5 \pm 1.5$, and $33.7 \pm 1.5$ visits/d, mean $\pm \mathrm{SE}$, calving day, $\mathrm{d} 1$, and $\mathrm{d} 2$ postcalving, respectively; $\mathrm{F}_{2,208}=4.30, P=0.01$ ).

The DS cows had a lower feeding rate than FS cows overall $(0.23 \pm 0.03$ vs. $0.28 \pm 0.03 \mathrm{~kg} / \mathrm{min}$, mean \pm SE; $\left.F_{1.110}=17.28, P<0.001\right)$ and a lower feeding rate on $\mathrm{d} 1$ and 2 postcalving $\left(F_{2,206}=7.29, P<0.001\right.$, Figure 5). Multiparous cows had a higher feeding rate than primiparous cows $(0.27 \pm 0.03$ vs. $0.24 \pm 0.03 \mathrm{~kg} /$ min, mean $\left.\pm \mathrm{SE} ; F_{1.110}=7.53, P<0.01\right)$.

Calving Difficulties. Treatment did not affect the number of stillborn calves (FS, $\mathrm{n}=2$; DS, $\mathrm{n}=2$ ) or the severity of calving. Results are presented as the number of events, with the percentage of the total number of

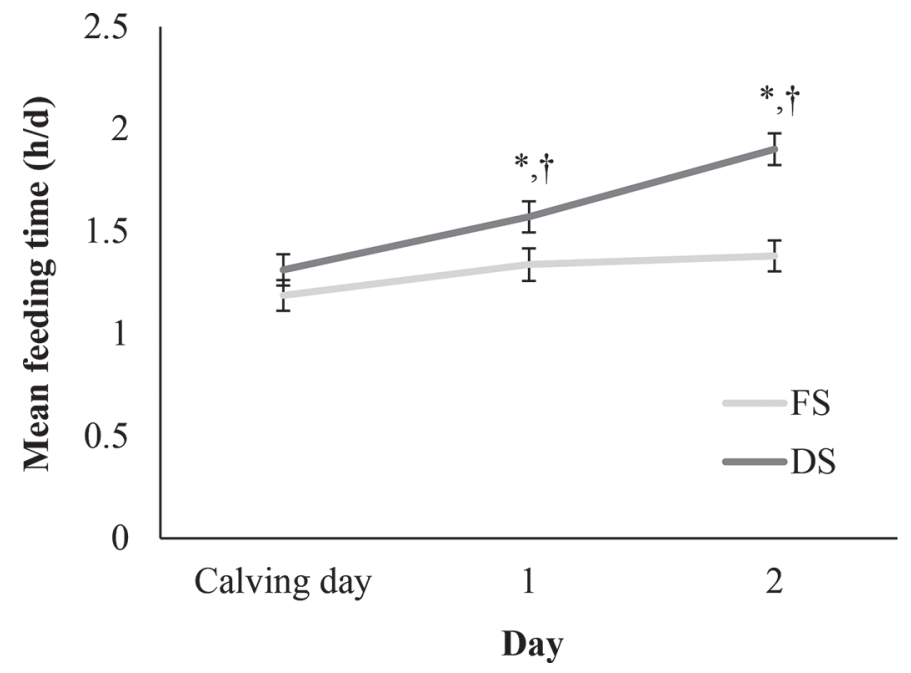

Figure 4. Mean $\pm \mathrm{SE}$ feeding time (h/d) postcalving for cows in freestalls ( FS, $\mathrm{n}=57$ ) and straw yards (DS, $\mathrm{n}=56) . \dagger=$ change in housing: DS cows remain in maternity pen; FS are moved to lactation pen. ${ }^{*}=P<0.05$, significant difference between treatments for day.

calvings in parentheses; unassisted calving $[\mathrm{FS}=40$ (66.5); DS $=32(57.0) ; \chi^{2}=0.66, P>0.1$, easy with help [FS $=15(25.0) ; \mathrm{DS}=15(27.0) ; \chi^{2}=0.02, P>$ $0.1]$, and hard with help [FS $=4$ (6.5); DS $=8$ (14.0); $\left.\chi^{2}=1.72, P>0.1\right]$. We did not obtain enough data to analyze the category of hard calvings with veterinarian assistance $\left[\mathrm{FS}=1(2.0)\right.$; DS $=1(2.0) ; \chi^{2}=$ not applicable], and cesarean [FS $=0(0) ; \mathrm{DS}=0(0) ; \chi^{2}=$ not applicable].

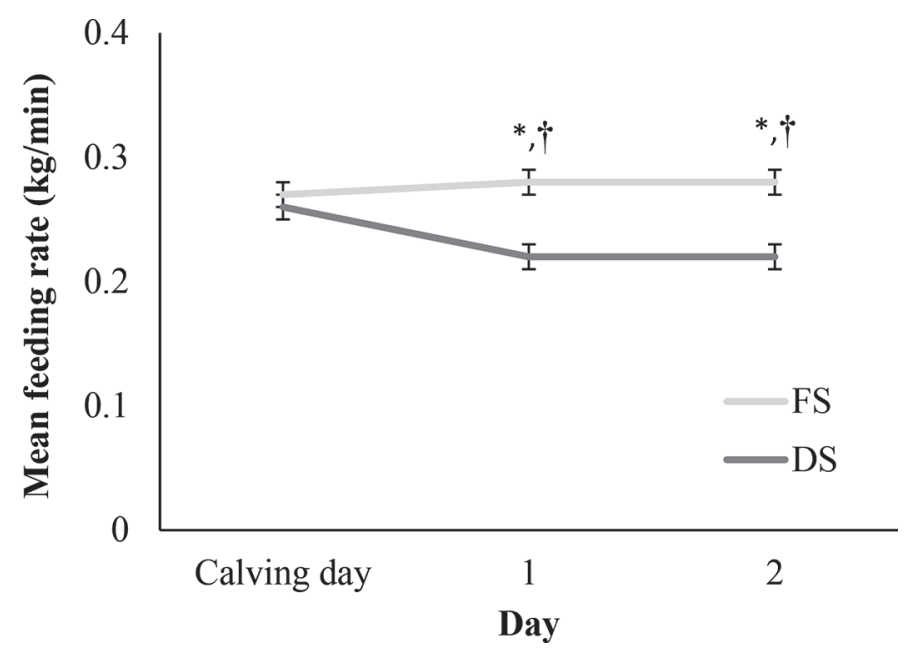

Figure 5. Mean $\pm \mathrm{SE}$ feeding rate $(\mathrm{kg} / \mathrm{min})$ postcalving for cows in freestalls (FS, $\mathrm{n}=57$ ) and straw yards (DS, $\mathrm{n}=56) . \dagger=$ change in housing: DS cows remain in maternity pen; FS are moved to lactation pen. ${ }^{*}=P<0.05$, significant difference between treatments for day. 


\section{DISCUSSION}

\section{Precalving}

Lying Behavior. Cows housed on straw had more lying bouts than FS cows, a result in agreement with our previous study (Campler et al., 2018) and with previous findings that cows housed on well-bedded surfaces had more lying bouts (e.g., Tucker and Weary, 2004). Our results were also in agreement with previous studies suggesting that soft bedding such as straw provides better traction and facilitates the process of lying down: for instance, a study on bulls by Ruis-Heutinck et al. (2000) and on dairy cows by Haley et al. (2001). However, our results showing an increased number of lying bouts in deep-bedded straw pens compared with cows in freestalls were in contrast to a study by Wechsler et al. (2000), which found no difference in the number of lying bouts between cows housed on straw or on lying mats in freestalls. Previous studies have also found that transition times between standing and lying were shorter on soft surfaces (e.g., Bak et al., 2016). We did not investigate transition times in this study, but we argue that in addition to the softer lying surface and added traction provided by straw, the lack of stall structures may enable cows to have more free and flexible transitions between standing and lying (see Campler et al., 2018). Moreover, straw is likely to provide additional traction during transition between standing and lying (or vice versa), when the cow is in need of secure footing and additional balance (Herlin, 1997). Additionally, the number of lying bouts increased closer to calving regardless of treatment, in agreement with previously reported behavioral patterns of increased restlessness in periparturient cows (e.g., Huzzey et al., 2005; Jensen, 2012; Sepúlveda-Varas et al., 2014).

The average lying times for both treatments were approximately $14 \mathrm{~h} / \mathrm{d}$ before calving, similar to findings in our previous study (Campler et al., 2018) and to findings by Kaufman et al. (2016) for cows during $2 \mathrm{wk}$ precalving. However, our findings were in contrast to a study by Fregonesi and Leaver (2001), who observed longer lying times in straw yards than in freestalls for lactating cows. It is likely that the comparison with our study reflects behavioral differences between dry and lactating cows, with a higher motivation in dry cows to lie down closer to calving. It is also possible that differences in freestall dimensions between studies may have influenced lying time results, because short and narrow stalls reduce lying time as reported for dry cows in a study by Tucker et al. (2004). As well, the observed high rate of social unrest or agonistic interactions in the straw yards (a factor not investigated in our study) may have mitigated any treatment differences by interrupt- ing lying bouts and reducing lying time for DS cows. In this study, we did find a higher number of lying bouts for DS cows than for FS cows precalving. As mentioned earlier, this could reflect the quality of the bedding material, but it could also be an indication of social unrest and displacement, reducing the total amount of time spent lying in DS cows. It is also possible that the motivation for lying down increases during later part of pregnancy, as both BW and body size increase closer to calving, making it more important to lie down, regardless of treatment. It is therefore plausible that similar mechanisms play a role in determining lying motivation during late gestation, overruling factors such as type of lying substrate and bedding thickness (e.g., Tucker et al., 2003; Cook et al., 2005; Reich et al., 2010).

Feeding Behavior. We observed no effect of treatment on feeding time, feed intake, or feeding rate, but DS cows had a more feeder visits than FS cows. All cows in this study were housed under the same stocking density and number of automatic feed bins, and fed the same diet precalving, so we expected few treatment effects. It is possible that DS cows were able to visit the feeders more frequently as a result of a more intermittent resting pattern, because the straw yard likely facilitated the transition between lying and standing as observed in DS cows in this study and in Campler et al. (2018). As expected, regardless of treatment, multiparous cows spent more time feeding and they had a higher feed intake and higher feeding rate than primiparous cows. We saw no effect of parity on the number of feeder visits, indicating that primiparous cows were able to use the automatic feed bins to the same extent as multiparous cows.

\section{Postcalving}

Lying Behavior. On the day after calving, DS cows showed a higher number of lying bouts than FS cows, and DS cows had longer lying times on d 2 and 3 postcalving than FS cows. The first finding was most likely because the straw bedding provided a non-slip surface supporting postural changes, but the longer lying times could have been a combined effect of a soft lying surface and remaining undisturbed by group members during the extended stay in the maternity pen. Cows that were housed in the maternity pen for the extended period postcalving did not experience any disturbance from other cows, whereas FS cows were subjected to a new social group in the lactation herd, which may have affected their lying behavior and reduced their lying time (Phillips and Rind, 2001; von Keyserlingk et al., 2008; Jensen and Proudfoot, 2017). The authors are aware that confounding factors in interpreting these 
results lie in the inability to distinguish the effect of the straw bedding, stall housing, being kept individually, and being introduced to a group; interpretations of these results should be undertaken with caution. The significant increase in lying time for DS cows postcalving suggests that an extended stay in the maternity pen may be beneficial in cow recuperation postcalving and should be investigated further.

Feeding Behavior. Cows housed in DS spent more time feeding, had a lower feeding rate, and visited the feeder more often than FS cows postcalving, but we observed no treatment effect on feed intake. The results most likely reflected the effect of regrouping in FS cows that were moved back to the lactation pen on the day after calving. As mentioned previously, the straw bedding could have facilitated the transition between lying and standing and could have encouraged cows to get up earlier to feed postcalving. However, regrouping has been reported to increase competition around the feed bunk (DeVries et al., 2004), reduce feeding time (DeVries et al., 2004; Huzzey et al., 2006; Shaver, 2012), and increase feeding rate (Proudfoot et al., 2018), in agreement with our postcalving results. It is possible that cows moved back to the lactation pen early postcalving are weaker and initially subordinate because of regrouping, and are therefore more unwilling to engage in confrontations to access their feed. Thus, it is possible that the FS cows in our study were less inclined to fight to access their allocated feed bin because of subordination and regrouping, resulting in fewer feeder visits overall. In our study, it is reasonable to assume that the maternity pen housing enabled DS cows to visit the feeder as they pleased without any disturbance from potential pen mates. This is reflected in the increased time spent feeding, as well as in the slower feeding rate in DS cows. On the other hand, a study by Schirmann et al. (2011) reported decreased feeding rates in cows that were regrouped in their home pen or regrouped into a new pen prepartum.

Calving Difficulties. We observed no difference in the number of unassisted or assisted calvings between treatments, in contrast to Campler et al. (2015), who found that the latency from visible feet to calf expulsion was shorter for cows previously housed on deep-bedded straw yards compared with freestalls during the dry period, indicative of an easier calving process when cows are housed on straw. However, the discrepancy between the 2 studies is likely due to differences in methodology and a lack of behavioral recordings of the calving process in the present study. Therefore, investigation of commercially viable management solutions, such as the effect of alternative transition cow housing on calving difficulties, should be pursued. Although this study does not investigate this topic in depth, we highly encourage future studies to do so.

\section{CONCLUSIONS}

The results from this study showed that housing cows on deep straw during the last 4 wk of the dry period facilitated the transition between lying and standing and increased the number of visits the feed bin, but it did not have a significant effect on lying and feeding behavior. However, the study results suggest potential benefits to giving cows additional recovery days in the maternity pen postpartum before moving them to the general lactation population postcalving. The extended stay in the maternity pen resulted in increased lying duration, increased feeding duration, and decreased feeding rate, and it eliminated any competition during the first sensitive days postcalving, when cows may be weak or susceptible to transition disease.

\section{ACKNOWLEDGMENTS}

The authors gratefully acknowledge help from the farm staff and technicians throughout this experiment. The work was supported by the Danish Cattle Federation (Aarhus, Denmark) and the Danish Ministry of Food, Agriculture and Fisheries (Copenhagen, Denmark).

\section{REFERENCES}

Adin, G., R. Solomon, M. Nikbachat, A. Zenou, E. Yosef, A. Brosh, A. Shabtay, S. J. Mabjeesh, I. Halachmi, and J. Miron. 2009. Effect of feeding cows in early lactation with diets differing in roughageneutral detergent fiber content on intake behavior, rumination, and milk production. J. Dairy Sci. 92:3364-3373. https://doi.org/ 10.3168/jds.2009-2078.

Bak, A. S., M. S. Herskin, and M. B. Jensen. 2016. Effect of sand and rubber surface on the lying behavior of lame dairy cows in hospital pens. J. Dairy Sci. 99:2875-2883. https://doi.org/10.3168/jds.2015 $-9937$.

Bossen, D., M. R. Weisbjerg, L. Munksgaard, and S. Højsgaard. 2009. Allocation of feed based on individual dairy cow live weight changes I: Feed intake and live weight changes during lactation. Livest. Sci. 126:252-272. https://doi.org/10.1016/j.livsci.2009.07.010.

Calamari, L., F. Calegari, and L. Stefanini. 2009. Effect of different freestall surfaces on behavioural, productive and metabolic parameters in dairy cows. Appl. Anim. Behav. Sci. 120:9-17. https://doi .org/10.1016/j.applanim.2009.05.013.

Campler, M., L. Munksgaard, and M. B. Jensen. 2015. The effect on calving behavior and calf vitality in Holstein and Jersey dairy cows. J. Dairy Sci. 98:1797-1804. https://doi.org/10.3168/jds.2014 -8726 .

Campler, M., L. Munksgaard, M. B. Jensen, D. M. Weary, and M. A. G. von Keyserlingk. 2014. Short communication: Flooring preferences of dairy cows at calving. J. Dairy Sci. 97:892-896. https:// doi.org/10.3168/jds.2013-7253.

Campler, M. R., M. B. Jensen, and L. Munksgaard. 2018. The effect of deep straw versus cubicle housing on behavior during the dry 
period in Holstein cows. Appl. Anim. Behav. Sci. 209:1-7. https:/ /doi.org/10.1016/j.applanim.2018.10.004.

Cook, N. B., T. B. Bennet, and K. V. Nordlund. 2005. Monitoring indices of cow comfort in free-stall-housed dairy herds. J. Dairy Sci. 88:3876-3885. https://doi.org/10.3168/jds.S0022-0302(05)73073 -3 .

Cook, N. B., R. L. Mentink, T. B. Bennet, and K. Burgi. 2007. The effect of heat stress and lameness on time budgets of lactating dairy cows. J. Dairy Sci. 90:1674-1682. https://doi.org/10.3168/ jds.2006-634.

Cooper, M. D., D. R. Arney, and C. J. C. Phillips. 2007. Two- or fourhour lying deprivation on the behavior of lactating dairy cows. J. Dairy Sci. 90:1149-1158. https://doi.org/10.3168/jds.S0022 -0302(07)71601-6.

DeVries, T. J., and M. A. G. von Keyserlingk. 2005. Time of feed delivery affects the feeding and lying patterns of dairy cows. J. Dairy Sci. 88:625-631. https://doi.org/10.3168/jds.S0022-0302(05)72726 -0 .

DeVries, T. J., M. A. G. von Keyserlingk, and D. M. Weary. 2004. Effect of feeding space on the inter-cow distance, aggression, and feeding behavior of free-stall housed lactating dairy cows. J. Dairy Sci. 87:1432-1438. https://doi.org/10.3168/jds.S0022 -0302(04)73293-2.

Drackley, J. K. 1999. Biology of dairy cows during the transition period: The final frontier? J. Dairy Sci. 82:2259-2273. https://doi .org/10.3168/jds.S0022-0302(99)75474-3.

Fisher, A. D., G. A. Verkerk, C. J. Morrow, and L. R. Matthews. 2002. The effects of feed restriction and lying deprivation on pituitary-adrenal axis regulation in lactating cows. Livest. Prod. Sci. 73:255-263. https://doi.org/10.1016/S0301-6226(01)00246-9.

Fregonesi, J. A., and J. D. Leaver. 2001. Behaviour, performance and health indicators of welfare for dairy cows housed in straw yard or cubicle systems. Livest. Prod. Sci. 68:205-216. https://doi.org/10 .1016/S0301-6226(00)00234-7.

Fregonesi, J. A., D. M. Veira, M. A. G. von Keyserlingk, and D. M. Weary. 2007. Effects of bedding quality on lying behavior of dairy cows. J. Dairy Sci. 90:5468-5472. https://doi.org/10.3168/jds.2007 $-0494$

Gomez, A., and N. B. Cook. 2010. Time budgets of lactating dairy cattle in commercial freestall herds. J. Dairy Sci. 93:5772-5781. https://doi.org/10.3168/jds.2010-3436.

Haley, D. B., A. M. de Passillé, and J. Rushen. 2001. Assessing cow comfort: Effects of two floor types and two tie stall designs on the behaviour of lactating dairy cows. Appl. Anim. Behav. Sci. 71:105-117. https://doi.org/10.1016/S0168-1591(00)00175-1.

Herlin, A. 1997. Comparison of lying area surfaces for dairy cows by preference, hygiene and lying down behaviour. Swed. J. Agric. Res. 27:189-196.

Huzzey, J. M., T. J. DeVries, P. Valois, and M. A. G. von Keyserlingk 2006. Stocking sensity and feed barrier design affect the feeding and social behavior of dairy cattle. J. Dairy Sci. 89:126-133. https: //doi.org/10.3168/jds.S0022-0302(06)72075-6.

Huzzey, J. M., M. A. G. von Keyserlingk, and D. M. Weary. 2005. Changes in feeding, drinking, and standing behavior of dairy cows during the transition period. J. Dairy Sci. 88:2454-2461. https:// doi.org/10.3168/jds.S0022-0302(05)72923-4.

Ingvartsen, K. L. 2006. Feeding- and management-related diseases in the transition cow: Physiological adaptations around calving and strategies to reduce feeding-related diseases. Anim. Feed Sci. Technol. 126:175-213.

Jensen, M. B. 2012. Behaviour around the time of calving in dairy cows. Appl. Anim. Behav. Sci. 139:195-202. https://doi.org/10 .1016/j.applanim.2012.04.002

Jensen, M. B., L. J. Pedersen, and L. Munksgaard. 2005. The effect of reward duration on demand functions for rest in dairy heifers and lying requirements as measured by demand functions. Appl. Anim. Behav. Sci. 90:207-217. https://doi.org/10.1016/j.applanim 2004.08.006.

Jensen, M. B., and K. L. Proudfoot. 2017. Effect of group size and health status on behavior and feed intake of multiparous dairy cows in early lactation. J. Dairy Sci. 100:9759-9768.
Kadivar, A., M. R. Ahmadi, and M. Vatankah. 2014. Associations of prepartum body condition score with occurrence of clinical endometritis and resumption of postpartum ovarian activity in dairy cattle. M. Trop. Anim. Health Prod. 46:121-126. https://doi.org/ 10.1007/s11250-013-0461-9.

Kaufman, E. I., S. J. LeBlanc, B. W. McBride, T. F. Duffield, and T. J. DeVries. 2016. Short communication: Association of lying behavior and subclinical ketosis in transition dairy cows. J. Dairy Sci. 99:7473-7480. https://doi.org/10.3168/jds.2016-11185.

Kok, A., R. J. van Hoeij, B. J. Tolkamp, M. J. Haskell, A. T. M. van Knegsel, I. J. M. de Boer, and E. A. M. Bokkers. 2017. Behavioural adaptation to a short or no dry period with associated management in dairy cows. Appl. Anim. Behav. Sci. 186:7-15. https://doi .org/10.1016/j.applanim.2016.10.017.

Metz, J. H. M. 1985. The reaction of cows to a short-term deprivation of lying. Appl. Anim. Behav. Sci. 13:301-307. https://doi.org/10 .1016/0168-1591(85)90010-3.

Munksgaard, L., M. B. Jensen, L. J. Pedersen, S. W. Hansen, and L. Matthews. 2005. Quantifying behavioural priorities - effects of time constraints on behaviour of dairy cows, Bos taurus. Appl. Anim. Behav. Sci. 92:3-14. https://doi.org/10.1016/j.applanim .2004.11.005.

Munksgaard, L., and H. B. Simonsen. 1996. Behavioral and pituitary adrenal-axis responses of dairy cows to social isolation and deprivation of lying down. J. Anim. Sci. 74:769-778. https://doi.org/10 $.2527 / 1996.744769 x$

Norring, M., E. Manninen, A. M. de Passille, J. Rushen, L. Munksgaard, and H. Saloniemi. 2008. Effects of sand and straw bedding on the lying behaviour, cleanliness, and hoof and hock injuries of dairy cows. J. Dairy Sci. 91:570-576. https://doi.org/10.3168/jds 2007-0452.

Phillips, C. J. C., and M. I. Rind. 2001. The effects on production and behavior of mixing uniparous and multiparous cows. J. Dairy Sci $84: 2424-2429$

Proudfoot, K. L., D. M. Weary, S. J. LeBlanc, L. K. Mamedova, and M. A. G. von Keyserlingk. 2018. Exposure to an unpredictable and competitive social environment affects behavior and health of transition dairy cows. J. Dairy Sci. 101:9309-9320. https://doi .org/10.3168/jds.2017-14115.

Randall, L. V., M. J. Green, M. G. G. Chagunda, C. Mason, S. C. Archer, L. E. Green, and J. N. Huxley. 2015. Low body condition predisposes cattle to lameness: An 8-year study of one dairy herd. J. Dairy Sci. 98:3766-3777. https://doi.org/10.3168/jds.2014-8863.

Reich, L. J., D. M. Weary, D. M. Veira, and M. A. G. von Keyserlingk. 2010. Effects of sawdust bedding dry matter on lying behavior of dairy cows: A dose-dependent response. J. Dairy Sci. 93:15611565. https://doi.org/10.3168/jds.2009-2713.

Ruis-Heutinck, L. F. M., M. C. J. Smits, A. C. Smits, and J. J. Heeres. 2000. Effects of floor type and floor area on behaviour and carpal joint lesions in beef bulls. Pages 29-36 in Improving Health and Welfare in Animal Production. EAAP publication 102. H. J. Blokhuis, E. D. Ekkel, and B. Wechsler, ed. Wageningen Pers, Wageningen, the Netherlands.

Schirmann, K., N. Chapinal, D. M. Weary, W. Heuwieser, and M. A. von Keyserlingk. 2011. Short-term effects of regrouping on behavior of prepartum dairy cows. J. Dairy Sci. 94:2312-2319. https:// doi.org/10.3168/jds.2010-3639.

Schirmann, K., N. Chapinal, D. M. Weary, W. Heuwieser, and M. A. G. von Keyserlingk. 2012. Rumination and its relationship to feeding and lying behavior in Holstein dairy cows. J. Dairy Sci. 95:3212-3217. https://doi.org/10.3168/jds.2011-4741.

Sepúlveda-varas, P., D. M. Weary, and M. A. G. von Keyserlingk. 2014. Lying behaviour and postpartum health status in grazing dairy cows. J. Dairy Sci. 97:6334-6343. https://doi.org/10.3168/ jds.2014-8357.

Shaver, R. D. 2012. Rumen acidosis in dairy cattle: Bunk management considerations. PhD Thesis. Department of Dairy Science, College of Agricultural and Life Sciences, University of Wisconsin-Madison. 
Tucker, C. B., N. R. Cox, D. M. Weary, and M. Ŝpinka. 2009. Laterality of lying behaviour in dairy cattle. Appl. Anim. Behav. Sci. 120:125-131. https://doi.org/10.1016/j.applanim.2009.05.010.

Tucker, C. B., and D. M. Weary. 2004. Bedding on geotextile mattresses: How much is needed to improve cow comfort? J. Dairy Sci. 87:2889-2895. https://doi.org/10.3168/jds.S0022-0302(04)73419 $-0$.

Tucker, C. B., D. M. Weary, and D. Fraser. 2003. Effects of three types of free-stall surfaces on preferences and stall usage by dairy cows. J. Dairy Sci. 86:521-529. https://doi.org/10.3168/jds.S0022 -0302(03)73630-3.

Tucker, C. B., D. M. Weary, and D. Fraser. 2004. Free-stall dimensions: Effects on preference and stall usage. J. Dairy Sci. 87:1208 1216. https://doi.org/10.3168/jds.S0022-0302(04)73271-3.

van Gastelen, S., B. Westerlaan, D. J. Houwers, and F. J. C. M. van Eerdenburg. 2011. A study on cow comfort and risk for lameness and mastitis in relation different types of bedding materials. J. Dairy Sci. 94:4878-4888. https://doi.org/10.3168/jds.2010-4019.

van Knegsel, A. T. M., G. J. Remmelink, S. Jorjong, V. Fievez, and B. Kemp. 2014. Effect of dry period length and dietary energy source on energy balance, milk yield, and milk composition of dairy cows. J. Dairy Sci. 97:1499-1512. https://doi.org/10.3168/jds.2013-7391.

Vickers, L. A., D. M. Weary, D. M. Veira, and M. A. G. von Keyserlingk. 2013. Feeding a higher forage diet prepartum decreases incidences of subclinical ketosis in transition dairy cows. J. Anim. Sci. 91:886-894. https://doi.org/10.2527/jas.2011-4349.

von Keyserlingk, M. A. G., D. Olenick, and D. M. Weary. 2008. Acute behavioral effects of regrouping dairy cows. J. Dairy Sci. 91:10111016. https://doi.org/10.3168/jds.2007-0532.

Wechsler, B., J. Schaub, K. Friedly, and R. Hauser. 2000. Behaviour and leg injuries dairy cows kept in cubicle systems with straw bedding or soft lying mats. Appl. Anim. Behav. Sci. 69:189-197. https: //doi.org/10.1016/S0168-1591(00)00134-9.

Westin, R., A. Vaughan, T. J. DeVries, E. A. Pajor, D. Pellerin, J. M. Siegford, E. Vasseur, and J. Rushen. 2016. Lying times of lactating cows on dairy farms with automatic milking systems and the relation to lameness, leg lesions, and body condition score. J. Dairy Sci. 99:551-561. https://doi.org/10.3168/jds.2015-9737. 